\title{
THE RELATIONSHIP BETWEEN SMOKING AND PERIODONTAL STATUS
}

N.A. Baharuddin, F.H. Al-Bayaty. The relationship

between smoking and periodontal status. Annal Dent Univ Malaya 2008; 15(2): 59-66.

\begin{abstract}
Objective: this study was carried out to evaluate the relationship between smoking and periodontal status in a selected Malaysian population. The sample for this cross-sectional study involved 39 subjects who were smokers. Each subject was required to answer the guided questionnaire followed by clinical examination. The questionnaires had 11 questions and were set in English and Bahasa Melayu. Basically, the questionnaire consisted of 3 sections: socio-demographic data, smoking status and subject's knowledge on periodontal health. The clinical parameters used in this study were: Community Periodontal Index, Visible Plaque score, Gingival Bleeding Index and Calculus Surface Index. Results showed that out of 39 subjects, 28 subjects $(71.8 \%)$ were current smokers, followed by 6 subjects $(15.4 \%)$ and 5 subjects $(12.8 \%)$ who were former and who never smoked respectively. From the 216 sextants examined, 42 sextants $(19.4 \%)$ were healthy gingival, 127 sextants $(58.8 \%)$ suffered from gingivitis and $47(21.8 \%)$ sextants suffered from periodontitis. There were positive relationships between smoking and periodontal status.
\end{abstract}

Key words: smoking; periodontal status

\section{INTRODUCTION}

Periodontal disease is a multi-factorial disease with bacterial plaque as the main etiology factor (1). However, the manifestation and progression of periodontitis is dependent on the host. Several risk factors such as smoking, drugs, nutrition, stress, hormone and systemic disease could have great influence on the oral disease progression (2). For many years, smoking has been linked to lung disease, cardiovascular disease, poor pregnancy outcomes, and oral diseases such as necrotizing ulcerative gingivitis (3).

The deleterious effects of smoking are partly due to impaired immune response towards bacterial challenge. Smoking has been shown to affect the chemotaxis and phagocytosis ability of the neutrophils (4) and to decreased neutrophils adherence ability (5). Neutrophils have been shown to have detrimental effects on cell movement and the oxidative burst. In vitro studies show that nicotine
Original Article

N.A. Baharuddin 1 , F.H. Al-Bayaty ${ }^{2}$
${ }^{1}$ Department of Oral Pathology
Oral Medicine and Periodontology
Faculty of Dentistry
${ }^{2}$ Department of Periodontology
Faculty of Dentistry
University Teknologi Mara
Corresponding author: F.H. Al-Bayaty

can inhibit production of super oxide and hydrogen peroxide by stimulated neutrophils which may inhibit microbial killing mechanisms and thus impaired the host's ability to combat periodontal infection (6).

In the past decade, there has been a change in the smoking trend. Although it was reported that the percentage of USA adults who smoke was declined but an increased among high school children who smoke was observed. Almost $25 \%$ of adults and $14 \%$ of youth smoke (7). Similarly, it was reported that $25 \%$ of Malaysian youth between the ages of 13 to 17 years old smoke. Children as young as 6 years old smoke in rural areas (8).

The prevalence of smoking among the younger population would mean that more and more people may suffer serious health problems as well as periodontal condition at an early age. This would represent a significant public health problem. The Malaysian Government has spent RM 100 million each year to fight smoking through its "Tak Nak" antismoking campaign (9). In view of the increase prevalence of smoking among Malaysians, it is appropriate to carry out this study to evaluate the relationship between smoking and the periodontal status in a selected Malaysian population.

\section{MATERIALS AND METHODS}

The sample for this cross-sectional study involved 39 subjects. The subjects recruited were either patients or those who accompanying patients to the Primary Care Unit (PCU), Faculty of Dentistry, University of Malaya. Explanation was given to each subject regarding procedures involved in this study. Each subject was required to answer a guided questionnaire followed by a clinical examination. All subjects were required to sign a written consent form prior to commencement of the study. The protocol for all procedures was approved by the Faculty of 
Dentistry, University of Malaya (ethic DFOP0603/ 0009(U)).

\section{Inclusion criteria}

1) Subjects who are cigarettes smokers.

2) Subjects must be at least 18 years old.

\section{Exclusion criteria}

1) Subjects who indicated the use of other forms of tobacco such as cigar, pipe, or smokeless tobacco.

2) Subjects who are pregnant and/or nursing mothers.

3) Subjects with systemic diseases such as cardiovascular, renal disease, diabetes mellitus.

\section{QUESTIONNAIRE}

A self administrated questionnaire survey with convenience sampling was used in this study. The questionnaire have 11 questions and were set in English and Bahasa Melayu. Basically, the questionnaire consisted of 3 sections:

Section A - socio-demographic data

Section B - smoking status

Section C - subject's knowledge of periodontal health

\section{Assessment of smoking status}

Using the criteria established by the Centre for the Disease Control and Prevention (CDC), current smokers were defined as those that had smoked over 100 cigarettes over their lifetime and smoked at the time of interview. Former smokers were those who smoked over 100 cigarettes in their lifetime but were not currently smoking, while non smokers were those who had not smoke over 100 cigarettes during their lifetime.

The questionnaire was pre-tested on a convenient sample of 10 subjects from the Primary Care Unit, Faculty of Dentistry, University of Malaya. Based on comments given during the trial run, the questionnaire was modified and finalized. The questionnaire took about 5 to 10 minutes to be completed by the majority of the participants.

\section{CLINICAL MEASUREMENTS}

The clinical parameters used in this study were:

- Community Periodontal Index (CPI- Ainamo et al, 1982) (10)

- Visible Plaque score (Ainamo \& Bay, 1975) (11)

- Gingival Bleeding Index (Ainamo \& Bay, 1975) (11)

- Calculus Surface Index (Ennever et al, 1961) (12)

\section{Community Periodontal Index (CPI)}

The University of Michigan "O" periodontal probe, with Williams marking was used for CPI measurements. In CPI, the dentition is divided into six sextants. The teeth included in these six sextants were:

\begin{tabular}{llll} 
UPPER & $17-14$ & $13-23$ & $24-27$ \\
\hline LOWER & $47-44$ & $43-33$ & $34-37$
\end{tabular}

The highest score for each sextant was recorded. The recording per sextant was based on findings from indicated index teeth. The index teeth to be examined were:

\begin{tabular}{|l|l|l|}
\hline 17,16 & 11 & 26,27 \\
\hline 47,46 & 31 & 36,37 \\
\hline
\end{tabular}

If no index teeth were present in a sextant qualifying for examination, all the remaining teeth in that sextant were examined (Ainamo \& Bay, 1982).

A score of 0-4 are recorded as followed:

$$
\begin{aligned}
0= & \text { no sign of disease } \\
1= & \text { gingival bleeding after gentle probing } \\
2= & \text { supragingival or subgingival calculus } \\
& \text { present } \\
3= & \text { a pocket depth of }(4 \mathrm{~mm} \text { and } 5 \mathrm{~mm}) . \\
4= & \text { a deeper pocket }(6 \mathrm{~mm} \text { and more) }
\end{aligned}
$$

Sextants with CPI score 0 represented healthy gingival condition. Sextants with a CPI score 1 and 2 represented a gingivitis. Score 3 and 4 represented areas of pocketing of $\geq 4 \mathrm{~mm}$.

Instead of scoring severity per tooth surfaces, the plaque, gingival bleeding and calculus recordings were based on the absence or presence of clinical findings as suggested by Ainamo and Bay (11). The resulting indices, the Visible Plaque Index (VPI), the Gingival Bleeding Index (GBI) and Calculus Surface Index (CSI) were reported as the number of teeth affected as a percentage to the number of teeth examined (excluding the wisdom teeth).

Such dichotomous scoring was adopted for epidemiological purposes by WHO (1978) and found to be suitable for clinical trial (11). The presence and absence of gingival bleeding was determined by gentle probing of the gingival crevice with the University of Michigan " 0 " periodontal probe with William's marking. The appearance of bleeding within 10 seconds indicated a positive score that was expressed as a percentage of the total number of gingival margin examined. The intra and interexaminer reproducibility was calculated from the difference between the 2 means for each duplicate to be analyzed. It was agreed that the reproducibility will be accepted when the examiners demonstrated 
measurements variable within a range of $\pm 1 \mathrm{~mm}$ over $80 \%$ of the time. Data presented in percentage.

\section{RESULTS}

Figure 1 illustrates that out of 39 subjects, 33 $(84.6 \%)$ belongs to the age group below 54 years old and the rests $(6,15.4 \%)$ were above 55 years of age, half of the sample (19) below the age of 34 year.

Figure 2 illustrates that 28 subjects $(71.8 \%)$ were current smokers, followed by 6 subjects $(15.4 \%)$ and 5 subjects $(12.8 \%)$ were former or never smokers respectively.

From the 216 sextants examined, generally the majority of the sample suffer from periodontal diseases, 42 sextants (19.4\%) were healthy, 127 sextants $(58.8 \%)$ suffered from gingivitis and 47 $(21.8 \%)$ sextants suffered from periodontitis (Figure 3).

\section{DISCUSSION}

All the subjects who participated in this study were either patients or next of kin of patients who came for dental treatment at the Primary Care Unit (PCU), Faculty of Dentistry, University of Malaya. Due to time and cost constraint, convenient sampling was chosen. Ideally, the randomized sample is preferred as it will eliminate conscious bias due to clinician or patient selection and minimize for unknown reasons. Bias can alter or distort the results. A larger number of samples could also reduce the bias. However, in this study the above were not possible due to time constraint. All the subjects are males. It was not inclusion criteria however the number of female smokers was so few; (at least in this selected population) they were excluded. Therefore, there was a gender bias in this study. It was reported that 25\% Malaysian youth smoke, between the ages of 13 to 17 years old.

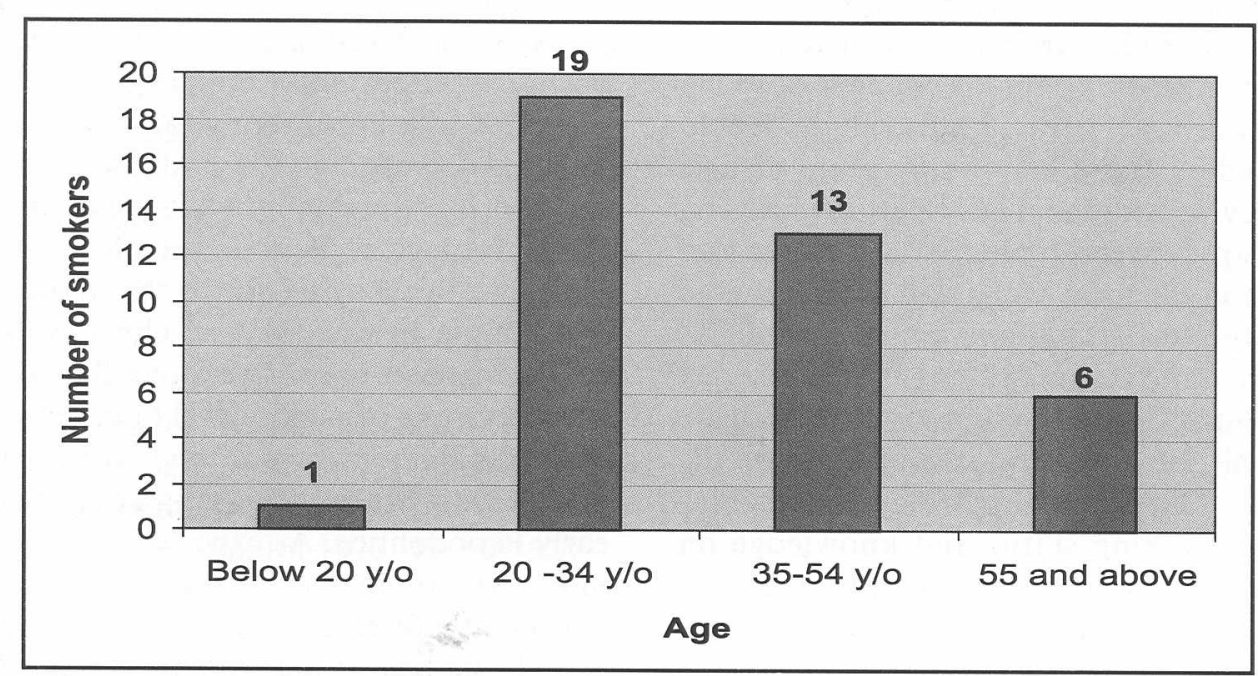

Figure 1: The distribution of subjects according to age groups $(n=39)$.

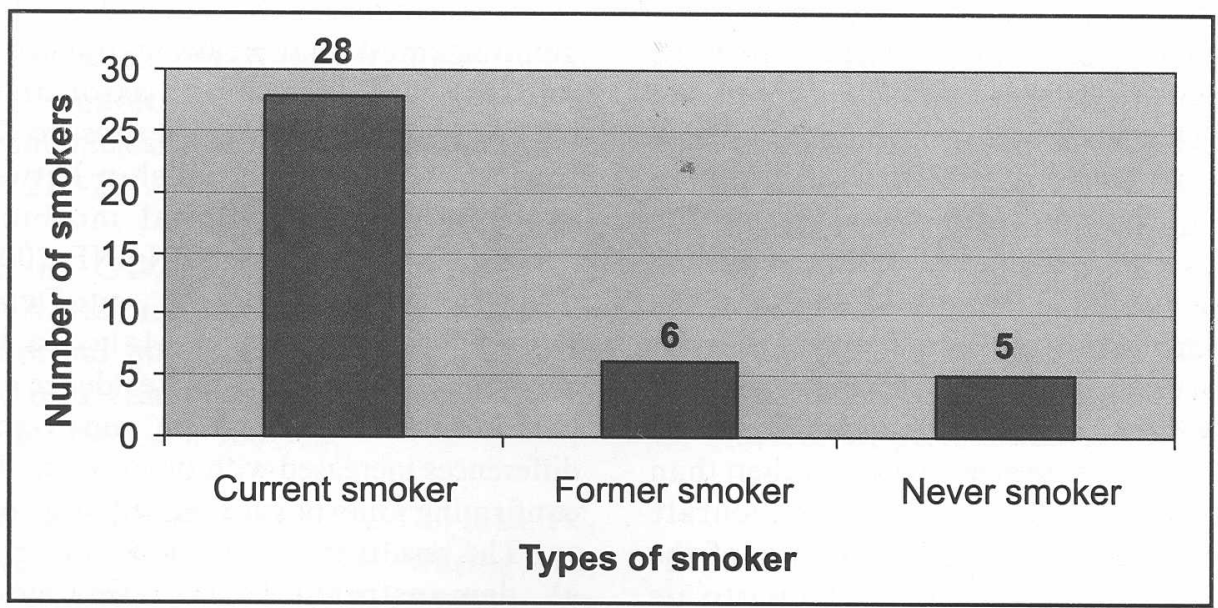

Figure 2: The distribution of type of smokers $(n=39)$. 


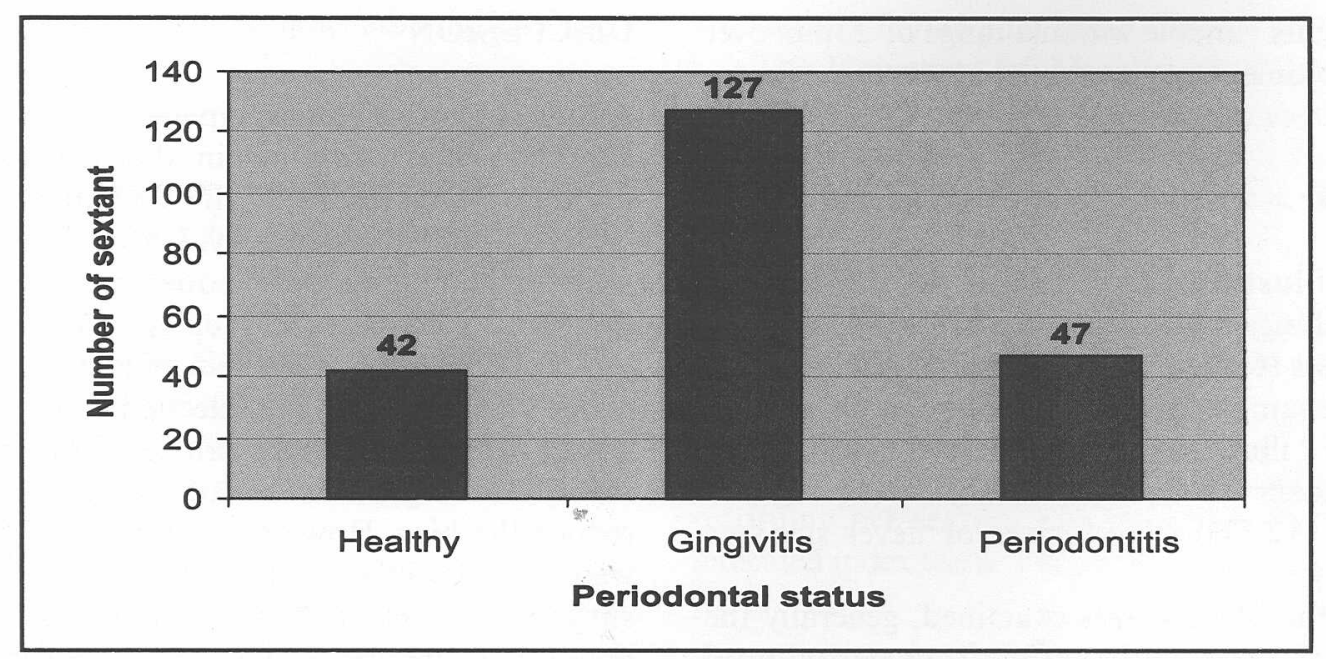

Figure 3: The distribution of periodontal status among the subjects $(n=216)$.

Children as young as 6 years old smoke in rural areas (NST, Aug. 18, 2005). The number of youth who smokes rose from 16.7\% in 1996 (Second National Health and Morbidity Survey) to $25 \%$ in $2005(8,9)$. The results indicated an even more alarming trend in smoking among children as young as 6 years old in rural areas. Future study should consider including those bellows 18 years of age. This could provide additional information regarding the relationship between periodontal statuses and smoking habit in the total Malaysian population.

This study consists of two parts i.e. guided questionnaire and clinical measurement of periodontal status. Upon consenting to participate in the study, all subjects were asked to answer the questionnaire. The questionnaire covered sociodemographic, smoking status and knowledge on periodontal health and was prepared in bilingual i.e. English and Bahasa Melayu. The authors were available to guide the subjects if required. The questionnaire took approximately five to seven minutes to be completed. This technique was selected suitabler a direct interview because it was the easiest method and was cost and time effective.

Self-reported had been shown to be a valid method for estimating smoking prevalence. However, the self reported was be based on patient recall and estimates (13). Thus, there were possibilities for recall bias to occur. In this study, CPI was used as a measurement of assessing periodontal status. The measurement by CPI is a simple, realistic screening and monitoring technique that provides most of the necessary information at first examination. It provides information on the severity of the periodontal condition around each index tooth and records the highest value per sextant rather than individual score. This gave the most accurate information about the periodontal condition of the individual. The authors choose CPI due to its simplicity, diagnostic speed and international uniformity.
The role of smoking as risk factors for periodontal disease is well documented. In this study, there were 28 subjects $(71.8 \%)$ who were current smokers, 6 subjects $(15.4 \%)$ who were former smokers and 5 subjects $(12.8 \%)$ who never smoked. From the 216 sextants examined, 42 sextants (19.4\%) presented with healthy gingival, 127 sextants $(58.8 \%)$ suffered from gingivitis and $47(21.8 \%)$ sextants suffered from periodontitis.It is not surprising that the percentage of Periodontitis lower than that for gingivitis, this may be due to that more than half of the sample below 35 year, chronic Periodontitis involve patients over 35 year old. Smoking can mask the early signs of periodontal disease by suppressing the inflammatory response (13-15). This can be a diagnostic problem, especially in young people with early Periodontitis. As expected we observe that the majority of the sextants (174) involved with periodontal disease.

The finding was consistent with another study by Bergstrom, Ellison, and Dock, who found that smokers had an inferior periodontal health condition compared to non-smokers. Current smokers had a significantly greater reduction in periodontal bone height as compared to non-smokers (16). It was also demonstrated that heavy exposure to cigarette smoking was consistently associated with more severe condition than light exposure. This in return suggests that the relationship between smoking exposure and periodontal morbidity is dosedependent to smoking KINANE 2000. The study done by Razali $M$ et al., at Dental Faculty, University Kebangsaan Malaysia in year 2005 confirmed that smokers had evidence of more severe periodontal disease than never-smokers. The differences increased with times of smoking exposure confirming an exposure-related response (17).

The results from the study done by Gonzalez et al. demonstrated that plasma cotinine levels correlated significantly with the number of cigarettes smoked per day. Moreover, heavy smokers had fewer 
teeth with no bone loss and more teeth with moderate bone loss than non-smokers (18). In the study done by Albandar et al. (19), on 705 subjects, who were current cigarette smokers had the highest prevalence of moderate and severe periodontitis $(25.7 \%)$ compared to former cigarette smokers $(20.2 \%)$, and non-smokers (13.1\%). Machuca et al. had done study on 304 healthy young males in order to relate association between cigarettes smoking and periodontal condition. It may be concluded that, even at such an early age, tobacco consumption affects the periodontal health. It is necessary to inform young smokers of the risk of tobacco use regarding periodontal health (20). A limitation of this study was the smale number of the sample, however the observation presented might give some clue about the positive relationship between smoking and periodontal status.

\section{CONCLUSION}

The majority of the sextants involved with periodontal disease. 127 sextants $(58.8 \%)$ suffered from gingivitis and $47(21.8 \%)$ sextants suffered from Periodontitis. Based on these findings we can conclude that, there was a positive relationship between smoking and periodontal status.

\section{REFERENCES}

1. Loe H, Anerud A, Boysen H, Smith M. The natural history of periodontal disease in man. The rate of periodontal destruction before 40 years of age. J Periodontol 1978, 49: 607-620.

2. Hart TE, Shapira L, Van Dyke TE. Neutrophils defect as risk factors for periodontal diseases. J Periodontol 1994. 65: 521-529.

3. Kinane DF. Smoking and priodontal disease. Crit Rev Oral Biol Med 200: 3, 356-365.

4. Kenney EB, Kraal JH, Saxe SR, Jones J. The effect of cigarette smoke on human oral polymorphonuclear leukocytes. J Periodont Res 1977. 12: 227-234.

5. MacFarlane GD, Herzberg MC, Woff LF, Hardie NA. Refractory periodontitis associated with abnormal polymorphonuclear leukocyte phagocytosis and cigarette smoking. J Periodontol 1992. 63: 908-913.

6. Pabst MJ, Pabst KM, Collier JA, Col-man TC, Lemons-Prince MR, Godat MS, Waring MB, Babu JP. Inhibition of neutrophils and monocyte defensive function by nicotine. J Periodontol 1995. 66: 908-913.
7. Garfinkel L. Trends in cigarettes smoking in the United States. Prev Med 1997. 26: 447-450.

8. Wikipedia Free Encyclopedia, News Straits Times, August 182005.

9. Wikipedia Free Encyclopedia, News Straits Times, August 232005.

10. Ainamo J, Barmes D, Beagrie G, Cutress T, Martin J, Sardo Infirri J. Development of the World Health Organization (WH, C) Community Periodontal Index of Treatment Needs (CPITN). Int. Dent. J. 1982. 32: 281-291.

11. Ainamo J, Bay I. Problems and proposal for recording gingivitis and plaque. Int. Dent. J. 1975. 25: 229.

12. Ennever J, Sterzenburger OP, Radike AW. The calculus surface index method for scoring clinical calculus studies.J Periodontol. 1961. 32: 54-57.

13. Haber J, Wattles J, Crowley M, Mandell R, Joshipura K, Kent RL. Evidence for cigarette smoking as a major risk factor for periodontitis. J Periodontol 1993. 64: 16-23.

14. Bergstrom J, Bostrom L. Tabacco smking and periodonal haemorrhagic responsiveness. J of Clin Periodontol 2001. 28: 680-685.

15. Dirtrich T, Bernimoulin JP, Glynn RJ. The effect of cigarette smoking on gingival bleeding $\mathrm{J}$ Periodontol 2004, 75: 16-22.

16. Bergstrom J, Eliasson S, Dock J. Exposure to tobacco smoking and periodontal health. J Clin Periodontol 1999, 26: 814-21.

17. Razali M, Palmer RM, Coward P, Wilson RF. A retrospective study of periodontal disease severity in smokers and non-smokers. Br Dent J. 2005. 198: 495-498; discussion 485.

18. Gonzalez YM, De Nardin A, Grossi SG, Machtei EE, Genco RJ, De Nardin E. Serum cotinine level smoking, and periodontal attachement loos, J. Dent Res., 1996: 75, 796802 .

19. Albandar JM, Streckfus CF, Adesanya MR, Win DM.Cigar, pipe, and cigarette smoking as risk factors for periodontal disease and tooth loss. $J$ Periodontol 2000. 71: 1874-81.

20. Machuca G, Rosales I, Lacalle JR, Machuca C, Bullon P. Effect of cigarette smoking on periodontal status of healthy young adults $\mathrm{J}$ Periodontol 2000, 71, 73-78. 


\section{SURVEY FORM:}

Mark $\sqrt{ }$ to your answer (Tandakan $\sqrt{\text { pada jawapan anda) }}$

PART A: DEMOGRAPEIC DATA (Bahagian A: Data Demografik)

\section{Gender / Jantina:}

Male

Lelaki

Female

Perempuan

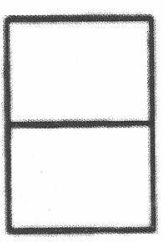

2. Age / Umur

Under 25 years

Bawak 25 tahun

25-34 years

25-34 tahun

$35-44$ years

$35-41$ tahun

45-54 years

45-51 tahen

55 years \& above

55 tahun \& ke ctas

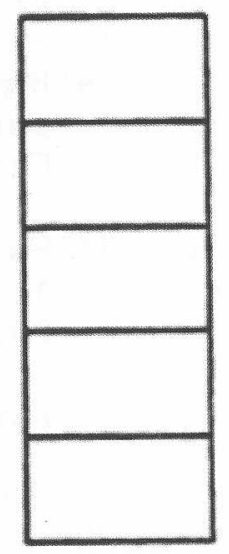

3. Ethnicity / Bangsa

Malay
Melayu
Chinese
Cina
Indian
India
Others
Lain-lain

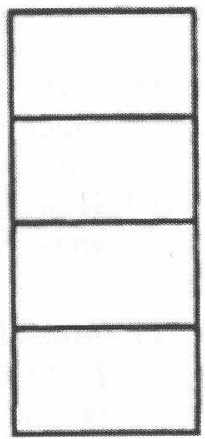




\section{Marital Status / Status Perkahwinan}
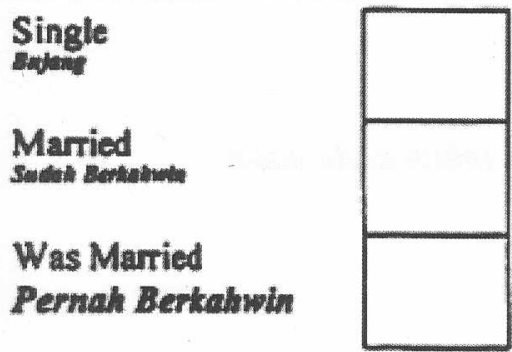

\section{Education Level / Tahap Pendiditan}

Secondary school or below

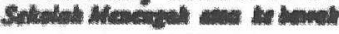

Undergraduate level Gerall injues and?

Post-graduate level

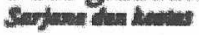

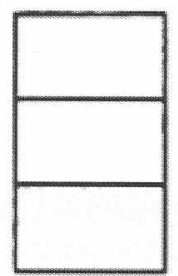

\section{PART B: EISTORES OF TOBACCO USE / SEJARAH PENGGUNAAN TEMBAKAU}

\section{Smoking Status / Status Perokok}

1. Current smoker (smokes over 100 cigarettes over lifetime and smoked at the time of the interview). If tick ( $(1)$, please answer question number 9

Perokok semasa (merokok lebih 100 batang sepanjang hayat dan merokok pada masa temuduga). Jika tanda (V), sila jawab soalan nombor 9

2. Former smoker (smokes over 100 cigarettes in lifetime but not currently smoked)

Pernah merokok (merokok lebih I00 batang sepanjang hagat dan letapi tidak merokok pada masa temuduge)

3. Non smoker (had not smoked over 100 cigarettes in lifetime)

Tidak pernah merokok (didak pernah merokok melebihl 100 batang sepanjang hayat)

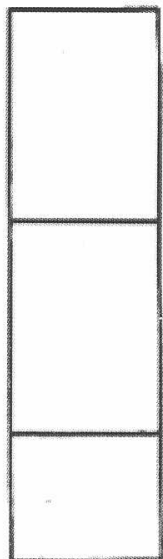

7. How many years you have been smoking? (Sudah berepa tehun anda merokok?)

8. How many cigarettes are you smoking per day? (Berapa batang anda merokok setiap harl?). 
9. What typed brands of cigirvtes do you smoke? (Nyadaken jenk rotok yang anda hasal.

10. Please state the main reason why you start smoking (Nyatakan sebab ende mule

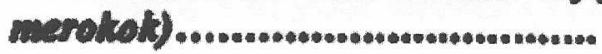

11. Did you notice any ord problen since you start smoking? (Adatali anda dped sebanens: masclah multet sejels anda muls moroloty

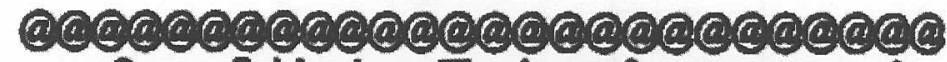

Survey finishes here. Thank you for your cooperation

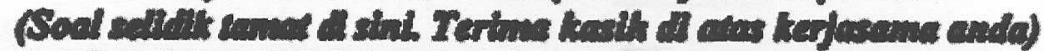

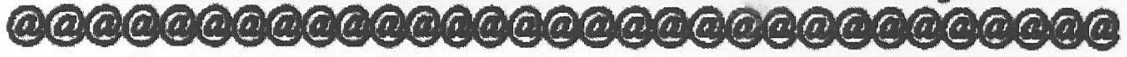

